\title{
Rice and wheat water productivity assessment in India
}

\begin{abstract}
Crop water productivity denotes the amount or value of product (i.e. crop or food) over volume or value of water used or depleted or diverted. It is dependent on water used in various production and agro-eco systems, level and scale of study. Assessment of crop water productivity helps in generating knowledge and information about water used by various users and committed losses. Crop water productivity is influenced by many factors and it can be improved if impact of various interventions on crop water productivity is known. In order to study the impact of various interventions on rice and wheat water productivity, it was computed from published data at different locations in the country and interventions showing higher values of water productivity were identified. The information generated from this study is useful in selecting and prioritizing suitable interventions to improve crop water productivity under prevailing constraints of limited availability of land, water and other input resources.
\end{abstract}

Volume 3 Issue 6 - 2018

\author{
Ashutosh Upadhyaya \\ Division of Land and Water Management, ICAR Research \\ Complex for Eastern Region, India
}

\begin{abstract}
Correspondence: Ashutosh Upadhyaya, Principal Scientist and Ex-Head, Division of Land and Water Management ICAR Research Complex for Eastern Region, Patna - 8000I4, Bihar, India, Email aupadhyaya66@gmail.com
\end{abstract}

Received: July 28, 2018 | Published: December 31, 2018

\section{Introduction}

According to Droogers \& Kite ${ }^{1}$ water is expected to be one of the most critical natural resources in the twenty-first century. Twenty-six countries are now classified as water deficient, and nearly 230 million people are affected with water shortages. Seckler et al. ${ }^{2}$ reported that by 2025 , one quarter of the world's population will face severe water shortages. To avoid social and environmental chaos, there is a clear need for better management of the limited amount of water available.

Seckler et al. $^{2}$ also reported that irrigated agriculture is the biggest consumer of world's fresh water resources. On a global level, irrigation comprises 72 percent of the average per capita diversions, with industrial and domestic sector accounting for 19 percent and 9 percent, respectively, of the average per capita water diversions. But in future share of water in agriculture sector is expected to reduce due to increased demand of industries, urban and domestic sectors.

Water being one of the most important inputs for crop production, adversely affects crop yield, when applied in excess or deficit at critical crop growth stages. Quality, quantity and time of input application have direct impact on crop yield and it is necessary to measure/ record and analyze the impact of one of the most important inputs i.e. water on yield to plan efficient and effective use of water resource in crop production.

The quantity of water application depends on many factors like size, shape and slope of field, method of irrigation, source and amount of water available, type of soil, type of crop and its' growth stage, socio-economic condition and awareness level of farmer about advanced agronomic and on-farm water management practices. Since time and quantity of water application have direct impact on crop yield it is necessary to record the time and scientifically measure the quantity of water applied (inflow to the field), water used by crop in transpiration, water stored in the root zone and water depleted from system in the form of evaporation, percolation and runoff.

The concept of productivity i.e., production per unit of input, focuses on limiting factors or constraints. In the mid 70s for example the petroleum crisis highlighted the importance of energy in agriculture and the productivity of energy became popular. In areas where labour is constrained, the concept of labour productivity is used. Water is also a limiting resource and water productivity also needs to be estimated for its judicious use.

Crop water productivity varies with location depending on the factors such as cropping pattern, climatic conditions, irrigation technology, field water management, infra structure and on the labour, fertilizer, and machinery inputs. According to Kijne et al., ${ }^{3}$ raising crop water productivity means raising crop yields per unit of water consumed, though with declining crop yield globally, the attention has shifted to potential offered by improved management of water resources. In general water productivity is a function of water applied, which depends on space scale and generally increases from small plots to large domains at basic scale because applied water is recycled and reused.

According to Molden, ${ }^{4}$ water productivity can be estimated at three levels: a use level such as an irrigated field or household, a service level such as an irrigation or water supply system, and a water basin level that may include several uses.

At the field level agronomists evaluate the productivity of water through water use efficiency, the ratio of yield to water consumed $(\mathrm{kg} /$ $\mathrm{m}^{3}$ ) by the crop through evapotranspiration at the field scale or as the yield per unit depth of water per area $\mathrm{kg} / \mathrm{ha} / \mathrm{mm}$. Biomass yield may also include straw and roots if they have an economic value. It can be estimated for individual crop or for a particular farm. Molden et al. ${ }^{5}$ discussed in detail the concept of water productivity and pathways to improve it. Chandra et al. ${ }^{6}$ computed crop water productivity in head, middle and tail reaches of RP Channel V under Patna Main canal in the Sone Command and two tube well commands in Vaishali, Bihar. They observed that crop water productivity varied in increasing order between 2.42 and $3.11 \% \mathrm{~m}^{3}$ from head to tail reach and 2.81 and $2.39 \% / \mathrm{m}^{3}$ in tube well 2 with land consolidation and tube well 1 with fragmented land holdings. Upadhyaya \& Sikka $^{7}$ also discussed the concept of water, land and energy productivity in agriculture and pathways for improvement.

Water productivity is influenced by many factors. Some of the important factors are: 
a. Source of water like rainfall, surface and ground water along with its' availability, accessibility and affordability

b. Water supply system like canal net work, ground water pumping and conveyance through pipes

c. Water application systems or irrigation methods i.e. surface irrigation like border, check basin or furrow irrigation or pressurized irrigation like sprinkler, micro sprinkler or trickle irrigation and various irrigation scheduling approaches

d. Social and economic conditions of water users/farmers

e. Land slope, leveling and drainage characteristics

f. Water losses as runoff, seepage or evaporation/evapotranspiration

g. Shape, size and slope of field

h. Infrastructure, labour, fertilizer, adoption level of farm mechanization, other on farm water management technologies, their cost effectiveness and sustainability, economics and policy interventions

i. Relationship between water suppliers and water users in canal command which helps in making water available to crop in time

j. Frequency, intensity, duration and distribution of rainfall and floods/drought or other climatic conditions

k. Type of soil, soil moisture level, infiltration, soil conservation and other soil health management practices,

1. crops, genetic material, various crop production, protection, improvement and management practices/ technologies

$\mathrm{m}$. Indigenous technical knowledge and superstitions of farmers

n. Training and awareness level of farmers to recent on farm water management technologies

o. Farmers' participation. In addition to these factors, application of quality inputs in appropriate quantity at right time with proper care/management throughout the process of farming, produced output, its' processing, value addition and linkage with suitable market to get appropriate price of produce also help in enhancing water productivity.

Water Productivity may be used as a quite effective management tool in

i. Benchmarking

ii. Identifying gaps and analyzing best ways to use water

iii. Identifying opportunities to reduce non-beneficial outflows from the domain

iv. Comparing productivity of water in different parts of the production system or basin, and

v. Deciding best possible multiple use combinations.

In the present paper rice and wheat water productivity has been estimated at different locations under different technical interventions to understand the variation of water productivity as influenced by various technologies/ practices/interventions.

\section{Materials and methods}

Published data from Annual Report (2014-15) ${ }^{8}$ about type of soil, depth of water table $(\mathrm{m})$, annual rainfall $(\mathrm{mm})$, source of irrigation and irrigation water quality at 21 water management centers located in major and medium irrigation commands and 4 water management centers located in hilly and high rainfall areas (Figure 1) under All India Coordinated Research Project on Water Management funded by Indian Council of Agricultural Research (ICAR) was collected and given in Table 1.

Table I Locality characteristics of AICRP centres in India

\begin{tabular}{|c|c|c|c|c|c|}
\hline Centre name & Soil type & $\begin{array}{l}\text { Depth of water } \\
\text { table }(\mathrm{m})\end{array}$ & $\begin{array}{l}\text { Annual } \\
\text { rainfall }(\mathrm{mm})\end{array}$ & $\begin{array}{l}\text { Source of } \\
\text { Irrigation }\end{array}$ & $\begin{array}{l}\text { Irrigation } \\
\text { water quality }\end{array}$ \\
\hline Belvatagi & Sandy loam to clay & Very deep & 556 & Canal & Good \\
\hline Bhavanisagar & Red sandy loam to clay loam & $3-10 \mathrm{~m}$ & 702 & Canal & Good \\
\hline Bilaspur & Sandy loam to clay & $>2 m$ & 1249 & Canal & Good \\
\hline Chalakudy & Loamy sand to sandy loam slightly acidic & $>2 m$ & 3146 & Canal & Good \\
\hline Chiplima & Sandy loam to sandy clay loam & $0.2-5 \mathrm{~m}$ & 1349 & Canal & Good \\
\hline \multirow[t]{2}{*}{ Faizabad } & Silty loam to silty clay loam & $3-4 m$ & 1163 & Canal & Good \\
\hline & & & & Tubewell & \\
\hline \multirow[t]{2}{*}{ Hisar } & Loamy sand to sandy loam & $0.4-1 \mathrm{~m}$ & 430 & Canal & Good \\
\hline & & & & Tubewell & \\
\hline Jammu & Sandy loam to silty loam & $>4 m$ & 1175 & Canal & Good \\
\hline \multirow[t]{2}{*}{ Jorhat } & Sandy loam to sandy clay loam, slightly acidic & $0-15 \mathrm{~m}$ & 1985 & Canal & Good \\
\hline & & & & Tubewel & \\
\hline Bathinda & Loamy sand to sandy loam & $1.0-4 \mathrm{~m}$ & 400 & Canal Tubewell & Good \\
\hline Kota & Clay loam to clay & $0.7-2 \mathrm{~m}$ & 777 & Canal & Good \\
\hline Madurai & Sandy loam to clay loam & $0.5-2 \mathrm{~m}$ & 858 & Canal & Good \\
\hline \multirow[t]{2}{*}{ Gayeshpur } & Sandy loam to clay loam & $0.2-2 \mathrm{~m}$ & 1315 & Canal & Good \\
\hline & & & & Tubewell & \\
\hline \multirow[t]{2}{*}{ Morena } & Sandy loam to sandy clay loam & $5-15 m$ & 875 & Canal & Good \\
\hline & & & & Tubewell & \\
\hline
\end{tabular}


Table Continued....

\begin{tabular}{|c|c|c|c|c|c|}
\hline Centre name & Soil type & $\begin{array}{l}\text { Depth of water } \\
\text { table }(\mathrm{m})\end{array}$ & $\begin{array}{l}\text { Annual } \\
\text { rainfall }(\mathrm{mm})\end{array}$ & $\begin{array}{l}\text { Source of } \\
\text { Irrigation }\end{array}$ & $\begin{array}{l}\text { Irrigation } \\
\text { water quality }\end{array}$ \\
\hline Navsari & Clayey & $\mathrm{I}-5 \mathrm{~m}$ & 1418 & Canal & Good \\
\hline \multirow[t]{2}{*}{ Pantnagar } & Sandy loam to clay loam & $0.5-3 \mathrm{~m}$ & 1370 & Canal & Good \\
\hline & & & & Tubewell & \\
\hline Parbhani & Medium to deep black clayey & $>3 m$ & 879 & Canal & Good \\
\hline Powarkheda & Clay loam to clayey & $\mathrm{I}-5 \mathrm{~m}$ & 1285 & Canal & Good \\
\hline \multirow[t]{2}{*}{ Pusa } & Sandy loam & $2-6 m$ & 1200 & Canal & Good \\
\hline & & & & Tubewell & \\
\hline Rahuri & Deep black clayey & $2-5 m$ & 523 & Canal & Good \\
\hline \multirow[t]{2}{*}{ Sriganganagar } & Loam to silty clay loam & $>10 \mathrm{~m}$ & 276 & Canal & Good \\
\hline & & & & Tubewell & \\
\hline Almora & $\begin{array}{l}\text { Brown forest and Podzolic soils, slightly } \\
\text { acidic }\end{array}$ & - & 1152 & - & - \\
\hline Dapoli & $\begin{array}{l}\text { Lateritic and alluvium derived soils-sandy } \\
\text { clay loam, slightly acidic }\end{array}$ & - & 3600 & - & - \\
\hline Palampur & $\begin{array}{l}\text { Brown forest and podzolic acidic soils-silty } \\
\text { clay loam, slightly }\end{array}$ & - & 2605 & - & - \\
\hline Shillong & $\begin{array}{l}\text { Red and lateritic soils-sandy loam, slightly } \\
\text { acidic }\end{array}$ & - & 2100 & - & - \\
\hline
\end{tabular}

\section{Crop water productivity computation}

Crop water productivity is the ratio of amount or value of product (i.e. crop) and the volume of water used or diverted or depleted. Increasing the productivity of water means, in its real sense, getting more benefit from every unit of water used for various crops. From farmers' view point, it means getting more production per unit of irrigation water. It is expressed in terms of $\mathrm{kg} / \mathrm{m}^{3}$ or $\mathrm{kg} / \mathrm{ha}-\mathrm{cm}$ or ${ }^{`} / \mathrm{m}^{3}$.

\section{Rice water productivity assessment}

Total water used by Rice under different resource conservation techniques and at various critical crop growth stages at Almora is given below in Table 2 .

Table 2 Rice water productivity under different treatments at Almora

\begin{tabular}{llll}
\hline Treatment details & Total water used $(\mathbf{m m})$ & Yield $(\mathbf{t} / \mathbf{h a})$ & Water productivity $\left(\mathbf{k g} / \mathbf{m}^{3}\right)$ \\
\hline Zero tillage & 707.4 & 2.8 & 0.396 \\
Conventional tillage & 737.9 & 3.02 & 0.409 \\
PSI + Tillering & 694.7 & 3.1 & 0.446 \\
PSI + Tillering + Panicle initiation & 743.9 & 3.14 & 0.422 \\
PSI + Tillering + Panicle initiation + Grain formation & 779.6 & 3.07 & 0.394
\end{tabular}

Rice water productivity varies between 0.394 to $0.446 \mathrm{~kg} / \mathrm{m}^{3}$ under various crop establishment and water application treatments at Almora. Two irrigations at Pre sowing and tillering stages give maximum water productivity. It indicates that PSI and tillering stages are very sensitive stages and under the situation of limited water availability irrigation should be provided at these stages of crop growth. When four irrigations at Pre sowing, tillering, Panicle initiation and Grain formation stages are applied, it gives the minimum water productivity because amount of water applied is more but yield is less. Water productivity is marginally lower in zero tillage treatment compared to conventional tillage method. It indicates that under limited water availability, zero tillage method should be preferred over conventional tillage method.

Rice water productivity was computed at Kurukshetra, Haryana considering total water used in rice production under bed planting and conventional tillage method and is given below in Table 3 .

Table 3 Rice water productivity at Kurukshetra, Haryana under bed planting and conventional tillage

\begin{tabular}{llll}
\hline Treatment details & Total water used $(\mathbf{m m})$ & Yield $(\mathbf{t} / \mathbf{h a})$ & Water productivity $\left(\mathbf{k g} / \mathbf{m}^{3}\right)$ \\
\hline Bed Planting & 1268.5 & 5.04 & 0.397 \\
Conventional tillage & 1817.2 & 5.53 & 0.3 \\
\hline
\end{tabular}


It is observed that Rice water productivity is more under Bed Planting method of crop establishment as compared to conventional tillage. Though yield is more in conventional tillage but water used is much less in bed planting method leading to higher water productivity under the treatment of bed planting.

Rice water productivity under various soil moisture regimes analyzed at Kanpur is presented below in Table 4.

Table 4 Rice water productivity under various soil moisture regimes at Kanpur

\begin{tabular}{|c|c|c|c|}
\hline Irrigation regime & $\begin{array}{l}\text { Relative grain } \\
\text { yield (\%) }\end{array}$ & $\begin{array}{l}\text { Irrigation } \\
\text { requirement (\%) }\end{array}$ & $\begin{array}{l}\text { Water productivity } \\
\text { enhancement }\end{array}$ \\
\hline Continuous submergence & 100 & 100 & I \\
\hline Continuous saturation & 92 & 56 & 1.64 \\
\hline $\begin{array}{l}\text { Saturation during early crop growth stage and submergence } \\
\text { thereafter }\end{array}$ & 100 & 88 & 1.13 \\
\hline $\begin{array}{l}\text { Submergence during active tillering upto flowering and } \\
\text { saturation during rest of the crop growth period }\end{array}$ & 104 & 66 & 1.58 \\
\hline $\begin{array}{l}\text { Saturation during active tillering upto flowering and } \\
\text { submergence during rest of the crop growth period }\end{array}$ & 80 & 75 & 1.07 \\
\hline
\end{tabular}

Rice Water productivity enhancement is found maximum under continuous saturation followed by submergence during active tillering upto flowering and saturation during rest of crop growth period. In these two methods, water saving is observed without reduction in yields so Rice water productivity is higher. The other two irrigation regimes better than continuous submergence from the view point of
Rice water productivity are (i) saturation during early crop growth stage and submergence thereafter followed by (ii) saturation during active tillering upto flowering and submergence during rest of the crop growth period.

Results of another study on Rice water productivity under deficit irrigation at Kanpur are presented below in Table 5.

Table 5 Rice water productivity under deficit irrigation at Kanpur

\begin{tabular}{llll}
\hline Soil moisture regime & Grain yield (t/ha) & Irrigation requirement $(\mathbf{c m})$ & Water Productivity $\left(\mathbf{K g} / \mathbf{m}^{3}\right)$ \\
\hline Saturation & 5.6 & 144 & 0.39 \\
Field capacity (FC) & 5.29 & 114 & 0.46 \\
$80 \%$ FC & 4.52 & 66 & 0.69 \\
$60 \%$ FC & 4.06 & 48 & 0.85 \\
\hline
\end{tabular}

Analysis indicates that Rice water productivity depends on soil moisture status and its utilization. Though irrigation at $60 \%$ of field capacity yields only $4.06 \mathrm{t} / \mathrm{ha}$ and continuous saturation yields $5.60 \mathrm{t} / \mathrm{ha}$ but Rice water productivity is higher $0.85 \mathrm{~kg} / \mathrm{m}^{3}$ in case of irrigation at $60 \%$ of field capacity as compared to $0.39 \mathrm{~kg} / \mathrm{m}^{3}$ in case of continuous saturation.

Rice water productivity under different depth of submergence and levels of nitrogen at West Bengal was computed and presented

Table 6 Rice water productivity at different levels of soil submergence and nitrogen levels in West Bengal in Table 6 below.

It may be observed that shallow water submergence and increasing level of nitrogen gives better rice water productivity. $120 \mathrm{~kg} / \mathrm{ha}$ level of Nitrogen and $5 \mathrm{~cm}$ depth of submergence gives Rice Water Productivity of $0.46 \mathrm{~kg} / \mathrm{m}^{3}$.

Rice water productivity values under continuous submergence and irrigation after 1,3 , and 5 days of drainage period at various locations were computed and given in Table 7.

\begin{tabular}{|c|c|c|c|c|c|}
\hline \multirow{2}{*}{ Depth of submergence $(\mathrm{cm})$} & \multicolumn{5}{|c|}{ Rice Water Productivity $(\mathrm{Kg} / \mathrm{m} 3)$ for different levels of Nitrogen $(\mathrm{Kg} / \mathrm{ha})$} \\
\hline & 0 & 40 & 80 & 120 & 160 \\
\hline 5 & 0.36 & 0.41 & 0.42 & 0.46 & 0.46 \\
\hline 10 & 0.24 & 0.28 & 0.31 & 0.31 & 0.29 \\
\hline 15 & 0.2 & 0.19 & 0.2 & 0.2 & 0.21 \\
\hline 20 & 0.13 & 0.15 & 0.16 & 0.15 & 0.17 \\
\hline
\end{tabular}


Table 7 Rice water productivity under continuous submergence and different drainage periods

\begin{tabular}{|c|c|c|c|c|c|}
\hline Location & $\begin{array}{l}\text { Irrigation water } \\
\text { saving with } \\
3 \text { days } \\
\text { drainage v/s } \\
\text { continuous } \\
\text { submergence (\%) }\end{array}$ & \multicolumn{4}{|c|}{ Rice Water Productivity $\left(\mathrm{Kg} / \mathrm{m}^{3}\right)$ under } \\
\hline Pusa (Bihar) & 43 & 0.443 & 0.578 & 0.707 & 0.814 \\
\hline Kharagpur (West Bengal) & 34 & 0.31 & 0.399 & 0.457 & 0.462 \\
\hline Bilaspur (M.P.) & 29 & 0.598 & 0.726 & 0.733 & 0.825 \\
\hline Pantnagar (Uttaranchal) & 44 & 0.669 & 0.68 & 0.82 & 1.153 \\
\hline Ludhiana (Punjab) & 40 & 0.291 & 0.375 & 0.453 & 0.542 \\
\hline Bhavanisagar (Tamil Nadu) & 41 & 0.336 & 0.463 & 0.619 & 0.756 \\
\hline Chalakudy (Kerala) & 55 & 0.248 & 0.546 & 0.704 & - \\
\hline
\end{tabular}

(

Figure 2 Water Productivity and Grain Yield of Wheat under different sowing methods.

Figure I Location of All India Coordinated Research Project on Water Management (AICRPWM) Centres in India (http://www.iiwm.res.in/aicrp.php).

It may be observed from the above Table that compared to continuous submergence, saving in irrigation water with 3 days desaturation/drainage period, varies in the range of 23 to $55 \%$ at various locations in India. As compared to continuous submergence, rice water productivity is higher under the cases when irrigation is applied after different days of drainage period and rice water productivity value increases when drainage period increases from 1 to 5 days. It is very evident from the above Table that continuous submergence in Rice doesn't enhance water productivity and water is not efficiently utilized by the crop leading to more water losses. So this practice should be discouraged.

\section{Wheat water productivity assessment}

Water productivity and wheat yield analysis under various resource conservation techniques such as Furrow irrigation raised bed (FIRB) planting, zero tillage and conventional tillage at Patna is presented below in Figure 2.

Analysis indicates that though wheat yield is more in zero tillage method followed by FIRB planting method as compared to conventional tillage method but water productivity is higher in FIRB followed by zero tillage method as compared to conventional tillage method.

Six field demonstrations conducted in Hisar on Outlet No. 14920L on FIRBS sowing and irrigation in wheat during 2014-15. The average grain yield was $4001 \mathrm{~kg} / \mathrm{ha}$ which was higher by $78 \mathrm{~kg}$ (2.01\%) over conventional sowing and surface irrigation. Under FIRBS, the amount of irrigation water applied was $2.1 \mathrm{~cm}(10.5 \%)$ less as compared to surface flood methods. Water productivity at the six farmers' fields varied between 145.5 to $212.7 \mathrm{~kg} / \mathrm{ha}-\mathrm{cm}$ with surface flood method while it varied between 210.7 to $242.9 \mathrm{~kg} / \mathrm{ha}-\mathrm{cm}$ with FIRBS and thus the increase in water productivity varied from 12.9 to $15.6 \%$. The average increase in water productivity was calculated to be $14.0 \mathrm{~kg} /$ ha-cm with FIRB.

The wheat water productivity computation at various locations in the country under different interventions based on input data collected from Annual Report (2003-04) ${ }^{9}$ was done considering total water used and is presented in Table 8.

The computed water productivity of wheat at various locations as 
shown in Table 8 indicate that it varied in the range of $0.715 \mathrm{~kg} / \mathrm{m}^{3}$ (only pre-sowing irrigation of $5 \mathrm{~cm}$ ) to $1.511 \mathrm{~kg} / \mathrm{m}^{3}$ (irrigation at CRI stage). Results also indicate that irrigation at most critical crop growth stages gives better water productivity compared to irrigation at all the stages or less sensitive stages. Resource conservation techniques indicate that bed planting method of wheat crop establishment yields

Table 8 Wheat water productivity at various locations under different interventions marginally better water productivity values compared to zero tillage and conventional tillage method.

Yadav etal. ${ }^{10}$ reported yield of wheat and total water used by wheat crop at optimum schedule of irrigation (based on IW/CPE ratio*) at different locations in India. Wheat water productivity was computed employing this data and is presented below in Table 9.

\begin{tabular}{|c|c|c|c|c|c|}
\hline S. No. & Place & Treatment details & $\begin{array}{l}\text { Total water } \\
\text { used }(\mathrm{mm})\end{array}$ & $\begin{array}{l}\text { Yield } \\
\text { (t/ha) }\end{array}$ & $\begin{array}{l}\text { Water Productivity } \\
\left(\mathrm{Kg} / \mathrm{m}^{3}\right)\end{array}$ \\
\hline \multirow{3}{*}{ I } & \multirow{3}{*}{ Pantnagar (Uttaranchal) } & Irrigation at CRI (Crown Root Initiation Stage) & 233 & 3.52 & 1.511 \\
\hline & & Irrigation at CRI+ Flowering & 293 & 3.53 & 1.205 \\
\hline & & Irrigation at CRI+ boot + milk stage & 353 & 4.55 & 1.289 \\
\hline \multirow{6}{*}{2} & \multirow{6}{*}{ Almora (Uttaranchal) } & Presowing Irrigation of $5 \mathrm{~cm}$ & 368 & 2.63 & 0.715 \\
\hline & & Post sowing only & 368 & 2.7 & 0.734 \\
\hline & & Pre sowing $+\mathrm{CRI}$ & 418 & 3.03 & 0.725 \\
\hline & & Pre sowing $+\mathrm{CRI}+\mathrm{IW} / \mathrm{CPE}=0.8$ & 468 & 3.44 & 0.735 \\
\hline & & Rainfed area & 421 & 4.13 & 0.98 \\
\hline & & Rainfed area & 455 & 3.99 & 0.877 \\
\hline \multirow{8}{*}{3} & \multirow{8}{*}{ Palampur (Himachal Pradesh) } & Furrow sowing + Irrigation at CRI & 277 & 2.26 & 0.816 \\
\hline & & Furrow sowing + Irrigation at CRI + boot stage & 342 & 2.93 & 0.857 \\
\hline & & Furrow sowing + mulch + irrigation at $\mathrm{CRI}$ & 280 & 3.07 & 1.096 \\
\hline & & Furrow sowing mulch + irrigation at CRI + boot stage & 345 & 3.39 & 0.983 \\
\hline & & Flat sowing + Irrigation at CRI & 279 & 2.13 & 0.763 \\
\hline & & Flat sowing + Irrigation at CRI + boot stage & 344 & 3.07 & 0.892 \\
\hline & & Flat sowing + mulch + irrigation at $\mathrm{CRI}$ & 283 & 3.03 & 1.071 \\
\hline & & Flat sowing + mulch + irrigation at CRI + boot stage & 346 & 3.33 & 0.962 \\
\hline \multirow{4}{*}{4} & \multirow{4}{*}{ Hissar (Haryana) } & Zero tillage & 410 & 4.229 & 1.031 \\
\hline & & Conventional & 422 & 4.127 & 0.978 \\
\hline & & Bed planting & 414 & 4.317 & 1.042 \\
\hline & & Conventional & 443 & 4.573 & 1.032 \\
\hline
\end{tabular}

Table 9 Wheat water productivity at different locations at optimum schedule of irrigations

\begin{tabular}{llllll}
\hline S. No. & Location & Optimum IW/CPE ratio & Grain yield (t/ha) & Total water use (mm) & Water Productivity $\left(\mathbf{k g} / \mathbf{m}^{3}\right)$ \\
\hline 1 & Belvatagi (Karnataka) & 0.9 & 3.81 & 390 & 0.977 \\
2 & Bikramganj (Bihar) & 0.9 & 2.64 & 238 & 1.109 \\
3 & Bilaspur (MP) & 0.9 & 4.01 & 245 & 1.637 \\
4 & Chiplima (Odisha) & 1.05 & 2.7 & 240 & 1.125 \\
5 & Faizabad (UP) & 1.05 & 4.01 & 240 & 1.671 \\
6 & Hisar (Haryana) & 1.05 & 3.85 & 370 & 1.041 \\
7 & Kharagpur (W.B.) & 0.75 & 2.82 & 336 & 1.639 \\
8 & Kota (Rajasthan) & 0.8 & 3.98 & 240 \\
9 & Madhepura (Bihar) & 0.6 & 2.4 & 120 & 1.095 \\
10 & Navasari (Gujarat) & 1.05 & 4.6 & 420 & 3.517 \\
11 & Pantnagar & 1.05 & 4.22 & $120 * *$ & 1.367 \\
12 & Rahuri (Maharashtra) & 1.05 & 4.1 & 300 & 0.585 \\
13 & Parbhani (Maharastra) & 0.75 & 2.41 & 412 & 2.25 \\
14 & Sriganganagar & 1.05 & 5.4 & 240 & \\
\hline
\end{tabular}

*IW/CPE ratio is Irrigation water/Cumulative Pan Evaporation ** shallow water table condition 
It may be observed from above that IW/CPE ratio at various locations ranged between 0.60 and 1.05. At 7 locations it was 1.05 , at 3 locations 0.90 and at 4 locations below 0.80 . Wheat water productivity ranged between as low as $0.585 \mathrm{~kg} / \mathrm{m}^{3}$ at Parbhani and as high as $3.517 \mathrm{~kg} / \mathrm{m}^{3}$ at Pantnagar. The reason for such variation in water productivity may be mainly attributed to soil type, climatic variation, farmer's awareness level, quality and quantity of inputs used and on-farm water management technologies adopted.

\section{Conclusion}

The above study indicates that water productivity may be used as a decision making tool as it considers not only the yield of produce but also the water applied and used. It is influenced by many factors like time, quantity and quality of inputs, methods of inputs application, outputs produced, technologies adopted, and overall management. Crop water productivity can be enhanced either by improving yields without increasing water consumption or sustaining yield and reducing water consumption. In future, diversion of water for agriculture will be reduced due to increased water requirement in other important sectors, so more efficient use of water in agriculture is required, which is possible if water productivity is enhanced. Rice and wheat water productivity can be enhanced by adopting need based, cost effective, identified resource conserving and appropriate on-farm water management technologies.

\section{Acknowledgments}

None.

\section{Conflicts of interest}

Author declares there is no conflict of interest.

\section{References}

1. Droogers P, Kite G. Estimating productivity of water at different spatial scales using simulation modeling. Sri Lanka: International Water Management Institute; 2001. 16 p.
2. Seckler D. The new era of water resources management: From "dry" to "wet" water savings. Sri Lanka: International Water Management Institute; 1996.

3. Kijne J, Braker R, Molden D. Improving water productivity in agriculture: Editors' Overview. Sri Lanka: International Water Management Institute; 2003.

4. Molden D. Accounting for water use and productivity. Sri Lanka: International Water Management Institute; 1997.

5. Molden D, Oweis TY, Steduto P, et al. Pathways for increasing agricultural water productivity. Water for Food Water for Life: A Comprehensive Assessment of Water Management in Agriculture. Taylor and Francis AS; 2007:279-314.

6. Chandra R, Gupta RK, Sikka AK, et al. Impact of conservation technologies on water use and water productivity in Pabnawa minor of Bhakra canal system. Rice-Wheat Consortium Technical Bulletin. 2007.

7. Upadhyaya A, Sikka AK. Concept of Water, Land and Energy Productivity in Agriculture and Pathways for Improvement. Irrigation \& Drainage Systems Engineering, OMICS International. 2016;5(1).

8. Annual Report 2014-15. All India Coordinated Research Project on Water Management. Water Technology Centre for Eastern Region renamed as ICAR Indian Institute of Water Management, Bhubaneswar, Orissa.

9. Annual Report 2003-04. All India Coordinated Research Project on Water Management. Water Technology Centre for Eastern Region, Bhubaneswar, Orissa- 751023, India.

10. Yadav RL, Singh SR, Prasad K, et al. Management of Irrigated Agro-ecosystem. Natural Resource Management for Agricultural Production in India. In: JSP Yadav, GB Singh, editors. International Conference on Managing Natural Resources for sustainable Agricultural Production in the $21^{\text {st }}$ Century. New Delhi, India; 2000:775-870. 